\title{
Correction to: vigiGrade: A Tool to Identify Well-Documented Individual Case Reports and Highlight Systematic Data Quality Issues
}

\author{
Tomas Bergvall $^{1} \cdot$ G. Niklas Norén ${ }^{1,2} \cdot$ Marie Lindquist $^{1}$
}

Published online: 12 March 2019

(c) The Author(s) 2019

\section{Correction to: Drug Safety 2014, 37:65-77 https://doi.org/10.1007/s40264-013-0131-x}

The article vigiGrade: A Tool to Identify Well-Documented Individual Case Reports and Highlight Systematic Data Quality Issues, written by Tomas Bergvall. G. Niklas Norén. Marie Lindquist, was originally published Online First without open access. With the author(s)' decision to opt for Open Choice the copyright of the article changed to (C) The Author(s) [2019] and the article is forthwith distributed under the terms of the Creative Commons Attribution-NonCommercial 4.0 International License (http://creativeco mmons.org/licenses/by-nc/4.0/), which permits any noncommercial use, duplication, adaptation, distribution and reproduction in any medium or format, as long as you give appropriate credit to the original author(s) and the source, a link is provided to the Creative Commons license and any changes made are indicated.
The original article can be found online at https://doi.org/10.1007/ s40264-013-0131-x.

Tomas Bergvall

tomas.bergvall@who-umc.org

1 Uppsala Monitoring Centre, WHO Collaborating Centre for International Drug Monitoring, Uppsala, Sweden

2 Department of Mathematicsm, Stockholm University, Stockholm, Sweden
Open Access This article is distributed under the terms of the Creative Commons Attribution-NonCommercial 4.0 International License (http://creativecommons.org/licenses/by-nc/4.0/), which permits any noncommercial use, distribution, and reproduction in any medium, provided you give appropriate credit to the original author(s) and the source, provide a link to the Creative Commons license, and indicate if changes were made. 